\title{
N-to-C Solid-Phase Peptide and Peptide Trifluoromethylketone Synthesis Using Amino Acid tert-Butyl Esters ${ }^{1)}$
}

\author{
William G. GuTHEIL* and Qingchai Xu \\ Division of Pharmaceutical Sciences, School of Pharmacy, University of Missouri-Kansas City; 5005 Rockhill Road, \\ Kansas City, Missouri 64110, U.S.A. Received December 25, 2001; accepted February 20, 2002
}

\begin{abstract}
Solid-phase peptide synthesis in the $\mathrm{N}$-to-C direction, opposite to the classical $\mathrm{C}$-to- $\mathrm{N}$ direction of peptide synthesis, provides the synthetically versatile $\mathbf{C}$-terminal carboxyl group for further modification into $\mathbf{C}$-terminally modified peptide mimetics. These are of general interest as potential bioactive agents, particularly as protease inhibitors. Elaboration of peptide mimetics on the solid-phase would facilitate synthesis of peptide mimetic combinatorial libraries. This report describes an effective strategy for solid-phase inverse peptide synthesis based on readily available amino acid tert-butyl esters. The potential of this approach for peptide mimetic synthesis is demonstrated by the solid-phase synthesis of two peptide trifluoromethylketones.
\end{abstract}

Key words peptide synthesis; peptide mimetic; solid-phase

Solid-phase peptide synthesis (SPPS) in the N-to-C direction (inverse SPPS), opposite to the classical C-to-N direction of peptide synthesis, ${ }^{2)}$ provides the synthetically versatile peptide C-terminal carboxyl group for further modification into C-terminally modified peptide mimetics. These are of general interest as potential bioactive agents, and of particular interest in the search for potent and specific protease inhibitors. In addition, the ability to elaborate the C-terminus on the solid-phase would facilitate the synthesis of combinatorial libraries of peptide mimetics. ${ }^{3-5)}$ Several strategies for inverse SPPS have been described. ${ }^{6-10)}$ Recently described strategies for inverse SPPS include using amino acid 9-fluorenylmethyl esters ${ }^{8)}$ amino acid tri-tert-butyloxysilyl esters, ${ }^{9)}$ and amino acid allyl esters. ${ }^{10)}$ These strategies appear less than ideal, since suitable amino acid derivatives are not generally available commercially and can be difficult to prepare, and due to instability of reactants and/or intermediates. Amino acid tert-butyl esters are easily prepared, stable, and a large selection are commercially available. Another advantage is that the well established chemistry, instrumentation, and side chain protecting groups developed for the analogous Boc strategy for normal phase SPPS syntheses can be used as guides in the development and application of amino acid tert-butyl ester based inverse SPPS. This report describes an amino acid tert-butyl ester based strategy for inverse SPPS of peptides and peptide trifluoromethylketones.

Our initial strategy for inverse SPPS used succinylated Pam resin, as illustrated by an example synthesis of the model peptide Suc-Ala-Leu-Pro-Phe (1) (Fig. 1). To compare different coupling procedures this model peptide was synthesized with dicyclohexylcarbodiimide (DCC)/ $N$-hydroxybenztriazol (HOBT), $O$-benzotriazol-1-yl-1,1,3,3-tetramethyluronium hexafluoro-phosphate (HBTU)/diisopropylethylamine (DIEA), and $O$-7-azabenzotriazol-1-yl-1,1,3,3-tetramethyluronium hexafluorophosphate (HATU)/2,4,6-trimethylpyridine (TMP) based coupling methods. With HBTU/DIEA both in situ and preactivation protocols were tested. After completion of chain assembly succinylated peptide was released from the solid support by treatment with trifluoromethanesulfonic acid (TFMSA)/trifluoroacetic acid (TFA), and products were analyzed by liquid chromatography (LC)/MS. Coupling with DCC/HOBT gave the target peptide $(60 \%)$ and two deletion peptides - Suc-Ala-Leu-Pro (20\%) and Suc-AlaPro-Phe $(20 \%)$ - resulting from incomplete incorporation of Phe and Leu residues respectively. HBTU/DIEA and HATU/TMP coupling methods yielded high purity $(>80 \%)$ target peptide.

To compare the effect of preactivation (resin attached carboxyl group activated prior to addition of the amino acid tert-butyl ester) with in situ activation (all reagents mixed together nearly at once) on racemization, peptide samples were synthesized with HBTU/DIEA both with in situ and preactivation, and analyzed for racemization using Marfey's reagent ${ }^{11,12)}\left(\mathbf{1}^{a)}\right.$ and $\mathbf{1}^{b)}$ in Table 1). The first and second residues underwent substantial racemization, with significantly less racemization observed for the second residue with in situ activation. A test was then made of the more efficient coupling agent HATU ${ }^{13)}$ (HATU/TMP method) with in situ activation (Table $1, \mathbf{1}^{c}$ ). This coupling method was previously reported to give good results in the silyl ester approach to inverse SPPS. ${ }^{9)}$ The peptide synthesized by the HATU/ TMP method gave only 5\% racemization in the second amino acid compared to more than $10 \%$ with the HBTU/ DIEA coupling method. However, substantial racemization of the first residue was still observed, possibly due to the succinate linker.

To test the possibility that the succinate linker was associated with significant racemization of the first amino acid residue, inverse SPPS using a $N^{\alpha}$-benzyloxycarbonyl (Z)Glu-OH derivatized Pam or derivatized MBHA resin was in-

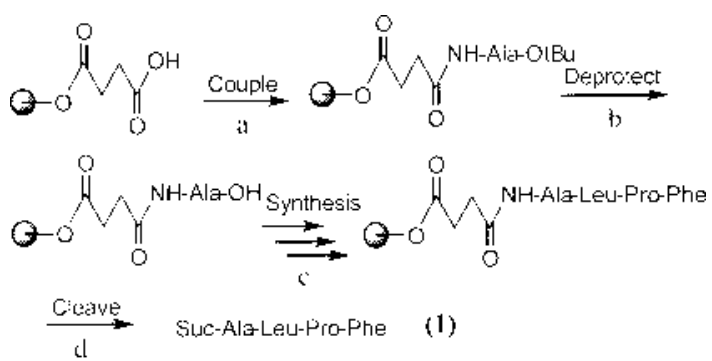

Fig. 1. Synthesis Strategy for Inverse SPPS on Succinylated Pam Resin Based on Amino Acid tert-Butyl Esters

(a) Coupling reagent; (b) $25-50 \% \mathrm{TFA} / \mathrm{DCM}$; (c) repeat (a) and (b); (d) TFMSA/TFA. 
Table 1. Percentage of D-Isomers Determined with Marfey's Reagent ${ }^{11,12}$ for the Indicated Peptides

\begin{tabular}{|c|c|c|c|c|c|c|c|c|c|}
\hline Peptide & D-Ala & D-Leu & D-Pro & D-Phe & D-Glu & D-Orn & D-Val & D-Lys & D-Asp \\
\hline $\mathbf{1}^{a)}$ & 26.8 & 22.8 & 1.8 & 1.6 & & & & & \\
\hline $\mathbf{1}^{b)}$ & 20.0 & 13.7 & 2.1 & 4.1 & & & & & \\
\hline $\mathbf{1}^{c)}$ & 37.6 & 5.4 & 1.1 & 1.4 & & & & & \\
\hline $\mathbf{2}^{c)}$ & 4.1 & & & 1.3 & 5.2 & & & & \\
\hline $3^{c)}$ & & & & & 3.3 & 1.2 & 4.7 & & \\
\hline $4^{c)}$ & 2.8 & & & & 2.4 & & & 1.8 & \\
\hline $\mathbf{5}^{c)}$ & & & 1.2 & 3.2 & 3.7 & & & & 1.2 \\
\hline
\end{tabular}

a) Prepared by HBTU/DIEA with preactivation method. b) Prepared by the in situ HBTU/DIEA method. c) Prepared by the in situ HATU/TMP method.

vestigated (Fig. 2). This linker possesses a protected $\alpha$ amino group, and given the low racemization seen in second and subsequent residue couplings with the HATU/TMP method it seemed reasonable to expect a Glu linker could suppress racemization seen in the first residue. Z-Glu-resin was prepared through coupling of Z-Glu-OtBu onto Pam or MBHA resin with DCC/DMAP or HATU/TMP respectively, followed by deprotection of the tert-butyl ester with TFA. Using this strategy peptides will have a Glu (with Pam resin) or a Gln (with MBHA resin) at the N-terminus. Several peptides were prepared with this strategy. Peptide 2 was synthesized on the Pam- $\gamma-\left(N^{\alpha}-\mathrm{Z}\right)$-Glu-OH resin while peptides $(3-5)$ were prepared on the MBHA- $\gamma-\left(N^{\alpha}-\mathrm{Z}\right)-\mathrm{Glu}-\mathrm{OH}$ resin. Peptides $\mathbf{2}$ and $\mathbf{3}$ were obtained in high purity $(>80 \%)$. Peptide 4 contained $20 \%$ of a side product that was identified by $\mathrm{LC} / \mathrm{MS}$ as peptide minus $\mathrm{MeOH}$, possibly due to partial ring closure between the Glu $\alpha$-COOMe and the Lys $\varepsilon-\mathrm{NH}_{2}$ during cleavage. Significant incomplete coupling was found in peptide 5 with about $30 \%$ of the deletion peptide Gln-ProPhe detected by LC/MS. Peptides $\mathbf{2}-\mathbf{5}$ were analyzed for degree of racemization by Marfey's method ${ }^{11,12)}$ (Table 1). The observed racemization of individual amino acids was generally less than $4 \%$ in peptides synthesized with the Glu/Gln linker strategy. These results demonstrate that the succinate linker was the cause of high racemization in the first residue, and this problem can be overcome through use of the Glu/Gln linker strategy.

The use of amino acid tert-butyl esters for inverse SPPS of peptide mimetics has also been investigated. Fluoromethyl ketones have been described as inhibitors of serine, cysteine, and aspartic acid proteases, including elastase, Cathepsin B, renin, and HIV protease. ${ }^{14-22)}$ Two peptide trifluoromethyl ketones have been synthesized based on the approach outlined in Fig. 3. Pam-Suc-Ala-Leu-Pro-Phe and MBHA- $\gamma$ $\left(N^{\alpha}\right.$-Z)-Glu-Ala-Glu $(\gamma-\mathrm{OMe})$-Lys $(\mathrm{Z})$ were coupled with an aminotrifluromethylalcohol ${ }^{16)}$ to give the corresponding tethered peptide trifluoromethylalcohols. Oxidation of the alcohol by Pfitzner-Moffat oxidation gave the corresponding peptidyl trifluoromethylketones. ${ }^{22,23)}$ The cleaved peptide trifluoromethylketones 6-7 were obtained in high purity ( $>80 \%$ in HPLC). In LC/MS they were detected as their hydrates. The lack of detectable peptide trifluoromethylalcohol indicated quantitative oxidation.

In summary, an amino acid tert-butyl ester based approach for inverse SPPS of short peptides and peptide mimetics has been developed. Succinylated Pam resin was first tested for synthesis of the model peptide Suc-Ala-Leu-Pro-Phe using several coupling methods, with the HATU/TMP giving the best results. A high degree of racemization was observed in

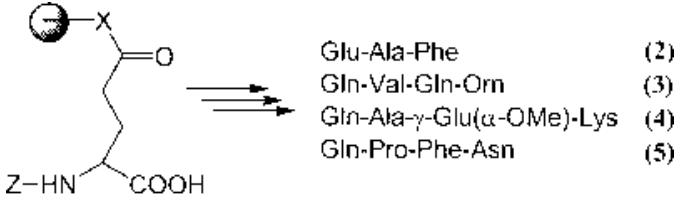

Fig. 2. Synthesis Strategy for Peptides $(\mathbf{2}-\mathbf{5})$ on Z-Glu-OH Derivatize Pam $(X=\mathrm{O}$, Glu Product) or MBHA ( $\mathrm{X}=\mathrm{NH}$, Gln Product) Resin with the HATU/TMP in Situ Activation Method

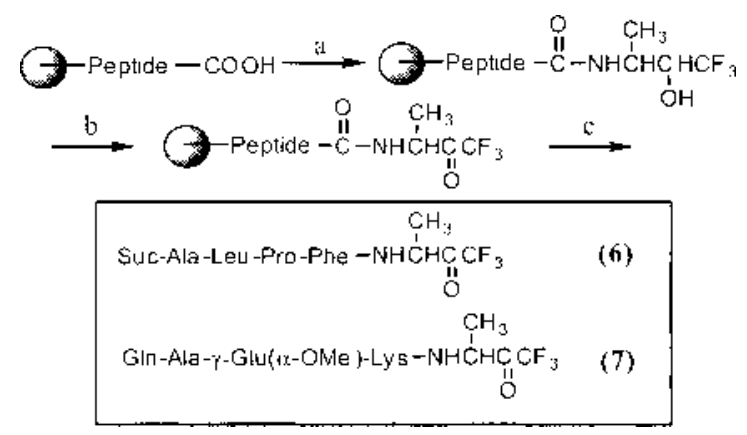

Fig. 3. Synthesis Strategy for Peptide Trifluoromethyl Ketones

(a) HATU/TMP, $\mathrm{NH}_{2} \mathrm{CH}\left(\mathrm{CH}_{3}\right) \mathrm{CH}(\mathrm{OH}) \mathrm{CF}_{3}$, in DMF for $2 \mathrm{~h}$; (b) DCC/CHCl ${ }_{2} \mathrm{COOH} /$ DMSO/toluene, $18 \mathrm{~h}$, then repeat once; (c) TFMSA/TFA, $2 \mathrm{~h}$.

the first residue regardless of coupling method, suggesting a possible effect of linker on racemization. In order to overcome this problem Z-Glu was tested as a linker on both Pam and MBHA resins. Combined with the HATU/TMP coupling method, several peptides were synthesized in high purity and with low racemization in all residues. Peptide trifluoromethylketones have also been prepared using this strategy, demonstrating the potential of the amino acid tert-butyl ester based inverse SPPS strategy for peptide mimetic synthesis. Peptides synthesized with the optimum strategy reported here have a Glu or Gln N-terminus. In some cases where a defined peptide sequence is desired this might be an impediment. For solid-phase combinatorial libraries these linkers will simply be an extension of the solid support. For solution phase combinatorial libraries these linkers will be remote from the Cterminal mimetic group and constant throughout the library, and are therefore expected to have minimal impact on library screening. These studies also demonstrate the use of the amino acid tert-butyl esters for inverse solid-phase synthesis of C-terminally modified peptide mimetics.

\section{Experimental}

General HPLC was performed on a Hewlett-Packard series 1050 system equipped with a diode array detector on C18 columns (Econosil, $4.6 \times 250 \mathrm{~mm}, 5.0 \mathrm{~mm}$ particles or Econosphere, $3.2 \times 250 \mathrm{~mm}, 5.0 \mathrm{~mm}$ particles). Compounds were separated by gradient elution; $0 \%$ of solvent $\mathrm{B}$ 
Table 2. Inverse SPPS Protocols ${ }^{a)}$

\begin{tabular}{lll}
\hline \hline Description & Reagent & Duration and repetition \\
\hline Protocol for the HOBT/DCC method with preactivation. & $1 \times 5 \mathrm{~s} ; 1 \times 30 \mathrm{~min}$ \\
OtBu deprotection & $25 \%$ TFA/DCM; $50 \%$ TFA/DCM & $3 \times 5 \mathrm{~s} ; 2 \times 5 \mathrm{~s} ; 3 \times 5 \mathrm{~s}$ \\
Washes & DCM; NMP; DCM & $10 \mathrm{~min}$ \\
Activation & $10 \times$ DCC/HOBT & $5 \mathrm{~h}$ \\
Coupling & $10 \times$ AA-OtBu $\cdot$ HCl/DIEA in NMP & $5 \times 5 \mathrm{~s}$ \\
Washes & NMP & $1 \times 5 \mathrm{~s} ; 1 \times 30 \mathrm{~min}$ \\
Protocol for the HBTU/DIEA method with preactivation. & $3 \times 5 \mathrm{~s} ; 2 \times 5 \mathrm{~s} ; 3 \times 5 \mathrm{~s}$ \\
OtBu deprotection & $25 \%$ TFA/DCM; $50 \%$ TFA/DCM & $30 \mathrm{~min}$ \\
Washes & DCM; NMP; DCM & $1 \times 5 \mathrm{~s}$ \\
Activation & $10 \times$ HBTU/DIEA & $2 \mathrm{~h}$ \\
Washes & NMP & $5 \times 5 \mathrm{~s}$ \\
Coupling & $5 \times$ AA-OtBu $\cdot$ HCl/DIEA in NMP & $1 \times 5 \mathrm{~s} ; 1 \times 30 \mathrm{~min}$ \\
Washes & NMP & $3 \times 5 \mathrm{~s} ; 2 \times 5 \mathrm{~s} ; 3 \times 5 \mathrm{~s}$ \\
Protocol for the HBTU/DIEA (or HATU/TMP) method with in situ activation. & $2 \mathrm{~h}$ \\
OtBu deprotection & $25 \%$ TFA/DCM; $50 \%$ TFA/DCM & \\
Washes & DCM; NMP; DCM & $5 \times 5 \mathrm{~s}$ \\
Activation/Coupling & $5 \times$ HBTU (or HATU), $5 \times$ AA-OtBu $\cdot \mathrm{HCl}, 10 \times$ DIEA & \\
Washes & (or TMP with HATU) in NMP & \\
\hline
\end{tabular}

a) $10 \times$ refers to 10 eq relative to resin.

( $0.1 \%$ TFA in $70 \%$ aqueous acetonitrile) in solvent $\mathrm{A}(0.1 \%$ TFA in water) for $1 \mathrm{~min}$, then $0 \%$ to $100 \%$ of solvent $\mathrm{B}$ in solvent $\mathrm{A}$ in $10 \mathrm{~min}$, and $0 \%$ to $100 \%$ of solvent $\mathrm{C}(0.09 \%$ TFA in acetonitrile $)$ in solvent B in $5 \mathrm{~min}$. LC/MS was carried out on an aQa ThemoQuest (Finnigan) system equipped with atmospheric-pressure ionization (API) electrospray source. Peptide synthesis was performed in small vials with a micro stir bar or on a multiblock synthesizer (CoshiSoft/PeptiSearch). Resin washings were performed with $\operatorname{DMF}(N, N$-dimethylformamide) and DCM (dichloromethane).

Succinylated Pam Resin Pam resin (1 eq) was swollen in DMF or NMP ( $N$-methylpyrrolidinone). A solution of succinic anhydride (10 eq) in DMF (or NMP) was added, followed by addition of a solution of DMAP (dimethylaminopyridine) (2 eq) in DMF (or NMP). The suspension was stirred at room temperature for $5 \mathrm{~h}$. The resin was washed and dried.

Loading of First Amino Acid tert-Butyl Ester onto Succinylated Resin with Preactivation Succinylated resin $(0.7 \mathrm{mmol} / \mathrm{g}, 1 \mathrm{eq})$ was pre-swollen in NMP. A solution of HBTU (or HATU) (10 eq) and DIEA (or TMP) (10 eq) in NMP was added. After stirring for $30 \mathrm{~min}$, the mixture was filtered and washed with NMP. To the resin was added a solution of amino acid tertbutyl ester ( $\mathrm{HCl}$ salt, $10 \mathrm{eq})$ and DIEA (10 eq). The suspension was mixed at room temperature for $2 \mathrm{~h}$. For DCC/HOBt coupling, a suspension of the succinylated resin together with a solution of DCC (10 eq), HOBT (10 eq), amino acid tert-butyl ester (HCl salt, $10 \mathrm{eq}$ ) and DIEA (10 eq) in NMP was stirred at room temperature for $5 \mathrm{~h}$. The resin was filtered, washed and dried. A small portion of the resin was subjected to Malachite Green test. ${ }^{24)}$ If the test was positive, the procedure described for loading of the first amino acid ester was repeated. If negative, the resin was treated with a solution of acetic anhydride ( 3 eq) and DIEA ( 3 eq) in NMP for $30 \mathrm{~min}$. The resin was washed and dried.

Loading of Z-Glu-OtBu onto PAM Resin PAM resin $(0.8 \mathrm{mmol} / \mathrm{g}$, $0.04 \mathrm{mmol}$ ) was swollen in DMF and then washed with $\mathrm{DMF} \times 3$. To the resin was added a solution of Z-Glu-OtBu $(0.2 \mathrm{mmol}, 5 \mathrm{eq}), \mathrm{DCC}(0.2 \mathrm{mmol}$, $5 \mathrm{eq})$ and DMAP $(0.2 \mathrm{mmol}, 5 \mathrm{eq})$ in NMP. The mixture was stirred for $4 \mathrm{~h}$. The resin was filtered and washed with DMF. A solution of acetic anhydride $(0.12 \mathrm{mmol})$ and DMAP $(0.12 \mathrm{mmol})$ in DMF was stirred with the resin for $30 \mathrm{~min}$ to cap unreacted hydroxyl groups. The resin was washed and dried.

Loading of Z-Glu-OtBu onto MBHA Resin MBHA resin $(0.8$ $\mathrm{mmol} / \mathrm{g}, 0.04 \mathrm{mmol}$ ) was swollen in DMF and then washed with $20 \%$ $\mathrm{DIEA} / \mathrm{DMF}$, and $\mathrm{DMF} \times 3$. To the resin was added a solution of Z-Glu-OtBu $(0.2 \mathrm{mmol}, 5 \mathrm{eq})$, HATU $(0.2 \mathrm{mmol}, 5 \mathrm{eq})$ and TMP $(0.2 \mathrm{mmol}, 5 \mathrm{eq})$ in DMF. The mixture was stirred for $3 \mathrm{~h}$. The resin was filtered and washed with DMF. A solution of acetic anhydride $(0.12 \mathrm{mmol})$ and DIEA $(0.12$ $\mathrm{mmol}$ ) in DMF was stirred with the resin for 30 min to cap unreacted amino groups. The resin was washed and dried.

Inverse Peptide Synthesis Peptides synthesis cycles were performed as summarized in Table 2.

$\mathbf{N O}_{2} \mathbf{C H}\left(\mathrm{CH}_{3}\right) \mathbf{C H}(\mathbf{O H}) \mathbf{C F}_{3}{ }^{16}$ Trifluoroacetaldehyde ethyl hemiacetal $(2.58 \mathrm{ml}, 20 \mathrm{mmol})$ and nitroethane $(1.58 \mathrm{ml}, 22 \mathrm{mmol})$ were stirred with
$\mathrm{K}_{2} \mathrm{CO}_{3}$ at $50^{\circ} \mathrm{C}$ for $5 \mathrm{~h}$. The reaction mixture was diluted with water and extracted with diethyl ether. The combined ether layers were washed with water and dried over $\mathrm{MgSO}_{4}$. Solvent was removed by evaporation, and the product distilled $\left(90^{\circ} \mathrm{C} / 10 \mathrm{~mm}\right)$.

$\mathbf{H C l} \cdot \mathbf{N H}_{2} \mathbf{C H}\left(\mathbf{C H}_{3}\right) \mathbf{C H}(\mathbf{O H}) \mathbf{C F}_{3}{ }^{16}$ ) A suspension of $\mathrm{NO}_{2} \mathrm{CH}\left(\mathrm{CH}_{3}\right) \mathrm{CH}$ $(\mathrm{OH}) \mathrm{CF}_{3}(1.0 \mathrm{ml})$ and Raney Nickel W-2 $(100 \mathrm{mg})$ in $10 \mathrm{ml}$ ethanol was stirred for $48 \mathrm{~h}$ under $50 \mathrm{psi}$ of hydrogen pressure. Solvent was removed by evaporation and the resulting residue was dissolved in $20 \mathrm{ml}$ of $1 \mathrm{~N} \mathrm{HCl}$. The aqueous solution was washed with ether. After lyophilization, $1.1 \mathrm{~g}$ of solid product was obtained. Single peak on HPLC. MS $[\mathrm{M}+\mathrm{H}]^{+}$143.4.

Pam-Suc-Ala-Leu-Pro-Phe-NHCH$\left(\mathrm{CH}_{3}\right) \mathrm{CH}(\mathrm{OH}) \mathrm{CF}_{3}$ and MBHA-

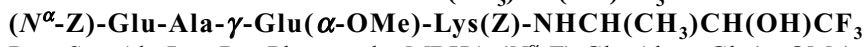
Pam-Suc-Ala-Leu-Pro-Phe and MBHA-( $\left.N^{\alpha}-\mathrm{Z}\right)$-Glu-Ala- $\gamma$-Glu $(\alpha-\mathrm{OMe})-$ $\operatorname{Lys}(Z)$ were subjected to HATU/TMP coupling with racemic 1-trifluoromethyl-2-amino-1-propanol $\left(\mathrm{HCl} \cdot \mathrm{NH}_{2} \mathrm{CH}\left(\mathrm{CH}_{3}\right) \mathrm{CH}(\mathrm{OH}) \mathrm{CF}_{3}\right)$. After filtration and washing, the resins were dried.

Pam-Suc-Ala-Leu-Pro-Phe-NHCH$\left(\mathrm{CH}_{3}\right) \mathrm{C}(\mathrm{O}) \mathrm{CF}_{3}$ and MBHA- $\left(N^{\alpha}-\right.$ Z)-Glu-Ala- $\gamma$-Glu( $\alpha$-OMe)-Lys(Z)-NHCH( $\left.\mathbf{C H}_{3}\right) \mathbf{C}(\mathbf{O}) \mathbf{C F}_{3}$ Pam-SucAla-Leu-Pro-Phe-NHCH$\left(\mathrm{CH}_{3}\right) \mathrm{CH}(\mathrm{OH}) \mathrm{CF}_{3}$ and MBHA- $\left(N^{\alpha}\right.$-Z)-Glu-Ala- $\gamma$ $\mathrm{Glu}\left(\alpha\right.$-OMe)-Lys(Z)-NHCH$\left(\mathrm{CH}_{3}\right) \mathrm{CH}(\mathrm{OH}) \mathrm{CF}_{3}$ were treated with a solution of $\mathrm{DCC} / \mathrm{CHCl}_{2} \mathrm{COOH} / \mathrm{DMSO} /$ toluene $(10 \mathrm{eq} / 1 \mathrm{eq} / 0.2 \mathrm{ml} / 0.2 \mathrm{ml})$ for $18 \mathrm{~h}$. After filtration and washing this procedure was repeated once. The resins were washed and dried.

Cleavage of Peptides from Resin Peptide-resin samples $(25 \mathrm{mg})$ were treated with $10 \%$ TFMSA/TFA $(10 \mu \mathrm{l} / 100 \mu \mathrm{l})$ for $30 \mathrm{~min}$ (succinylated resin) or $120 \mathrm{~min}$ (MBHA resin). The cleavage solution was sampled and analyzed by HPLC and LC/MS, and the remaining peptide was either diluted with water and lyophilized, or precipitated with ether.

Determination of Racemization by Marfey's Method ${ }^{11,12)}$ Crude peptide was dissolved in $1 \mathrm{ml}$ of $6 \mathrm{~N} \mathrm{HCl}$ in sealed vials, and heated to $120-$ $130^{\circ} \mathrm{C}$ for $3 \mathrm{~h}$. Solvent was removed under vacuum. Each hydrolyzed sample or D and L amino acid standard was dissolved in $50 \mu \mathrm{l}$ of water. To each solution was added $100 \mu 1$ of $5 \%$ Marfey's reagent (1-fluoro-2,4-dinitrophenyl-5-L-alanine) in acetone, followed by addition of $20 \mu 11 \mathrm{~m} \mathrm{NaHCO}$. The mixtures were heated to $30-40^{\circ} \mathrm{C}$ for $1 \mathrm{~h}$ and then quenched by addition of $50 \mu \mathrm{l}$ of $1 \mathrm{~m} \mathrm{HCl}$. Solvent was removed under vacuum. Each residue was dissolved in $0.5 \mathrm{ml}$ of DMSO. The derivatized amino acid mixtures were subjected to HPLC analysis (Econosil or Econosphere C18 column, $3.2 \times 250 \mathrm{~mm}, 5.0 \mathrm{~mm}$ particles; $0 \%$ to $80 \%$ of B in A, over $60 \mathrm{~min}$, flow rate $0.6 \mathrm{ml} / \mathrm{min}$, detection at $340 \mathrm{~nm}$ ). By comparison of the peak areas the percentage of D-diastereomer for each amino acid in each hydrolyzed sample was determined.

Acknowledgments We gratefully acknowledge support by NIH Grant GM60149 and funds from the University of Missouri. 


\section{References and Notes}

1) Presented in part at the 17th annual American Peptide Symposium and the 2nd annual International Peptide Symposium, San Diego CA, June 9-14, 2001. The methods described here are covered in Provisional U.S. Patent Application 60/293, 273.

2) Merrifield R. B., J. Am. Chem. Soc., 85, 2149-2154 (1963).

3) "Combinatorial Chemistry; Syntheses and Applications," ed. by Wilson S.R., Czarnik A. W., John Wiley \& Sons, New York, 1997.

4) "Combinatorial Chemistry and Molecular Diversity in Drug Discovery," ed. by Gordon E. M., Kerwin J. F., John Wiley \& Sons, New York, 1998.

5) Bunin B. A., “The Combinatorial Index," Academic Press, San Diego, 1998.

6) Letsinger R. L., Kornet M. J., J. Am. Chem. Soc., 85, 3045-3046 (1963).

7) Felix A. M., Merrifield R. B., J. Am. Chem. Soc., 92, 1385-1391 (1970).

8) Henkel B., Zhang L., Bayer E., Liebigs Ann./Recieul, 1997, 21612168 (1997).

9) Johansson A., Åkerblom E., Ersmark K., Lindeberg G., Hallberg A., J. Comb. Chem., 2, 496-507 (2000).

10) Thieriet N., Guibé F., Albericio F., Org. Lett., 2, 1815-1817 (2000).

11) Marfey P., Carlsberg Res. Commun., 49, 591—596 (1984).

12) Adamson J. G., Hoang T., Crivici A., Lajoie G. A., Anal. Biochem.,
202, 210-214 (1992)

13) Carpino L. A., J. Am. Chem. Soc., 115, 4397-4398 (1993).

14) Gelb M. H., Svaren J. P., Abeles R. H., Biochemistry, 24, 1813-1817 (1985).

15) Rasnick D., Anal. Biochem., 149, 461-465 (1985).

16) Imperialli B., Abeles R. H., Tetrahedron Lett., 27, 135-138 (1986).

17) Thiasrivongs S., Pals D. T., Kati, W. M., Turner S. R., Thomasco L. M., Watt W., J. Med. Chem., 29, 2080-2087 (1986).

18) Rauber P., Angliker H., Walker B., Shaw E., Biochem. J., 239, 633640 (1986).

19) Imperiali B., Abeles R. H., Biochemistry, 25, 3760-3767 (1986).

20) Dreyer G. B., Metcalf B. W., Tomaszek T. A., Carr T. J., Chandler A. C., Hyland L., Fakhoury S. A., Magaard V. W., Moore M. L., Strickler J. E., Debouck C., Meek T. D., Proc. Natl. Acad. Sci. U.S.A., 86, 9752-9756 (1989).

21) Govardhan C. P., Abeles R. H., Arch. Biochem. Biophys., 280, 137146 (1990).

22) Fearon K., Spaltenstein A., Hopkins A. B., Gelb M. H., J. Med. Chem., 30, 1617-1622 (1987).

23) Pfitzner K. E., Moffat J. G., J. Am. Chem. Soc., 87, 5661-5670 (1965).

24) Attardi M. E., Porcu G., Taddei M., Tetrahedron Lett., 41, 7391-7394 (2000). 